\title{
HERITABILITY ESTIMATES OF LITTER SIZE IN PIGS
}

\section{H. WILLEKE* and L. RICHTER**}

*Lehrstuhl für Tierzucht 8050 Freising-Weihenstephan, B.D.R. ** Versuchsgut Hülsenberg, 2362 Hïlsenberg, B.D.R.

From 1972 to 1977 data of litter size has been collected in one herd. The data were analysed by the method of Least-Squares for estimating the variance components and simultaneously adjusted for the fixed effects of litter number and mating partner. The $h^{2}$-estimates of litter size at birth calculated by this method are $h^{2}{ }_{s}=.06 \pm .04$ and $h^{2}{ }_{d}=.45 \pm$. Io, which agrees

TABLE I

Analysis of variance of litter size at birth

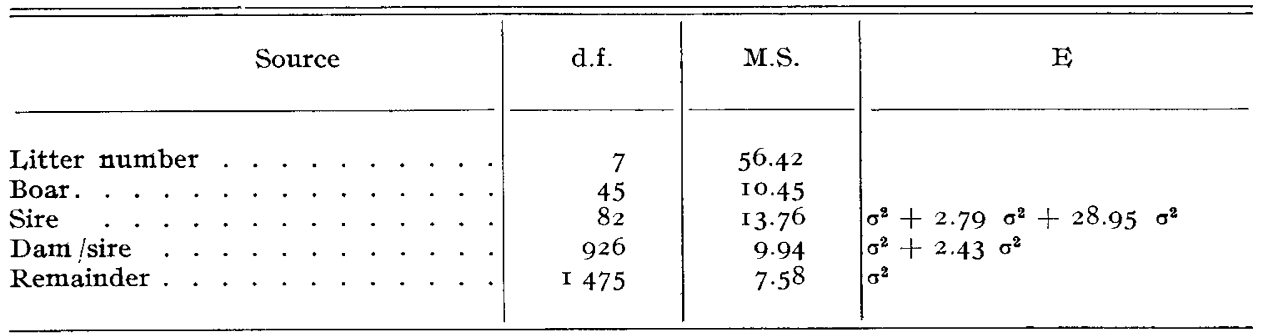

$h^{2}=.06 \pm .04 \quad h^{2}=.45 \pm .10$

with other authors (table I). As there may be the possibility that the statistical model doesn't fit with the biological model, theretore we estimated the linear regressions between different combinations of litter number of the dam and the daughter (table 2). The regression of daughter on dam (combination $I: I$ ) is very low; but the other combinations are even on a higher level than the estimates of REVELLE et al. (I973) and ALSING (1977). But ALSING (1977) estimated a similar low of regression for the first parities of the dams and the daughters. The parity combination I:I probably suffers lack of information of the different stages of the maturity of the guilts. In the second parity the differences of the stage of the maturity are more or less

TABLE 2

Daughter-dam regression for litter size at birth

\begin{tabular}{|c|c|c|c|c|c|c|c|}
\hline \multicolumn{3}{|c|}{ Parity } & \multirow{2}{*}{$\begin{array}{l}\text { Number } \\
\text { of pairs }\end{array}$} & \multirow{2}{*}{\multicolumn{2}{|c|}{$b+s_{b}$}} & \multirow{2}{*}{$s_{\text {dam }}$} & \multirow{2}{*}{$s_{\text {daughter }}$} \\
\hline dam & & daughter & & & & & \\
\hline $\mathbf{I}$ & I & . . & 725 & .036 & .041 & 2.17 & 2.42 \\
\hline $\mathbf{I}$ & & . . . . . & 380 & $.15 \mathrm{I}$ & .077 & .07 & 3. I I \\
\hline 2 & & $. \quad . \quad$. & $64 I$ & .124 & .038 & 2.72 & 2.66 \\
\hline 2 & & . . . . . & 320 & .143 & .062 & 2.75 & 3.08 \\
\hline
\end{tabular}


eliminated and the sow can show its true genetic capacity in a better way. Avoiding the parity combination I:I the heritability estimates by regression are in line with the estimates of REVELIE et al. (1973), ALSING (1977), OLLIVIER (I973) and HANRAHAN et al. (1974) and worth while to be integrated into a breeding programme.

BENÜTZUNG DER INDEXZAHLEN, DIE BEI DER ZUCHTWERTSCHÄTZUNG DER SCHWEINE IN UNGARN VERWENDET WERDEN

\author{
J. KOVACS \\ Agravwissenschaftliche Universität Keszthely, \\ Lehrstuhl für Tierzucht, Keszthely, Ungarn
}

Der Verfasser stellt die Indexzahlen vor, die in der Schweinezucht in Ungarn benutzt werden. Er macht uns mit der Kennziffer der Exterieursbeurteilung bekannt. Der auf Grund der in der Leistungskontrolle erhaltenen Angaben der zukünftigen Zuchttiere (JUNGEBER und JUNG$\mathrm{SAU})$ bestimmter Index wird dargestellt.

Er orientiert über den Index, der auf den zentralen Teststationen bei der Beurteilung der Frohwüchsigkeit, Futterverwertung und des Schlachtwertes der Jungeber verwendet wird.

Ausserdem wird die einheitliche Kennziffer, die aus den Daten der Mast-und Schlachtleistung auf den Teststationen gebildet wird, dargelet. Der Verfasser zeigt an, dass die Zuchtpraxis diese Daten parallel und einander ergänzend benutzt und auf solcher Weise, dass die Nachteile der mechanischen Anwendung vermeidet werden sollen.

\title{
II. - Facteurs génétiques et de milieu influençant la résistance naturelle aux maladies
}

\author{
GENETIC VARIATION IN MINERAL METABOLISM IN RELATION TO DISORDERS \\ G. WIENER \\ A.R.C. Animal Breeding Research Organisation, \\ West Mains Road, Edinburgh EH9 $3 \mathrm{JQ}$, Scotland
}

Evidence is reviewed of genetic variation in the incidence of disorders associated with the metabolism of minerals in general and trace elements in particular. Also reviewed is the evidence for genetic variation in the concentrations of various minerals and trace elements in blood and tissues of animals. Particular illustrations are given from work involving copper in sheep. The evidence suggests that breeds and strains of animals differ in their nutrient requirements for trace elements and probably other minerals, for the prevention of disorder and possibly for optimum performance.

AN ASSESSMENT OF GENETICAL METHODS IN THE CONTROL OF SCRAPIE

\section{R. H. KIMBERLIN}

A.R.C. Institute for Research on Animal Diseasses, Compton, Newbury, Berkshire, England

Scrapie is caused by a virus-like agent which is transmitted to sheep by horizontal and vertical routes of infection. The disease can be controlled by selective culling of bloodline relatives of serapie cases. However, this depends on accurate breeding records which are often not available. Two major studies, with Cheviot and with Herdwick sheep, have shown that " sus- 